\title{
Ethnobotanical appraisal and cultural values of medicinally important wild edible vegetables of Lesser Himalayas-Pakistan
}

Arshad Mehmood Abbasi ${ }^{* *}$, Mir Ajab Khan², Munir H Shah³, Mohammad Maroof Shah', Arshad Pervez and Mushtaq Ahmad²

\begin{abstract}
Background: The association among food and health is momentous as consumers now demand healthy, tasty and natural functional foods. Knowledge of such food is mainly transmitted through the contribution of individuals of households. Throughout the world the traditions of using wild edible plants as food and medicine are at risk of disappearing, hence present appraisal was conducted to explore ethnomedicinal and cultural importance of wild edible vegetables used by the populace of Lesser Himalayas-Pakistan.
\end{abstract}

Methods: Data was collected through informed consent semi-structured interviews, questionnaires, market survey and focus group conversation with key respondents of the study sites including 45 female, 30 children and 25 males. Cultural significance of each species was calculated based on use report.

Results: A total of 45 wild edible vegetables belonging to 38 genera and 24 families were used for the treatment of various diseases and consumed. Asteraceae and Papilionoideae were found dominating families with (6 spp. each), followed by Amaranthaceae and Polygonaceae. Vegetables were cooked in water (51\%) followed by diluted milk (42\%) and both in water and diluted milk (7\%). Leaves were among highly utilized plant parts (70\%) in medicines followed by seeds (10\%), roots (6\%), latex (4\%), bark, bulb, flowers, tubers and rhizomes (2\% each). Modes of preparation fall into seven categories like paste (29\%), decoction (24\%), powder (14\%), eaten fresh (12\%), extract (10\%), cooked vegetable (8\%) and juice (4\%). Ficus carica was found most cited species with in top ten vegetables followed by Ficus palmata, Bauhinia variegata, Solanum nigrum, Amaranthus viridis, Medicago polymorpha, Chenopodium album, Cichorium intybus, Amaranthus hybridus and Vicia faba.

Conclusions: Patterns of wild edible plant usage depend mainly on socio-economic factors compare to climatic conditions or wealth of flora but during past few decades have harshly eroded due to change in the life style of the inhabitants. Use reports verified common cultural heritage and cultural worth of quoted taxa is analogous. Phytochemical analysis, antioxidant activities, pharmacological applications; skill training in farming and biotechnological techniques to improve the yield are important feature prospective regarding of wild edible vegetables.

Keywords: Ethno-medicinal, Cultural values, Wild edible vegetables, Lesser Himalayas

\footnotetext{
* Correspondence: amabbasi@ciit.net.pk

${ }^{1}$ Department of Environmental Sciences, COMSATS Institute of Information

Technology, Abbaottabad, Pakistan

Full list of author information is available at the end of the article
} 


\section{Introduction}

Since the beginning of human civilization, people have used plants as food and medicine. The ethnobotanical pharmacology is as old as man himself. In Indo-Pak first record of plant medicine were compiled in Rig Veda between 4500-1600 BC and Ayurveda between 2500600BC [1]. Ethnobotany deals with past and present interrelationships between human cultures and the plants. The investigation of the cultural values of plant species plays a significant role to modern medicine, farming, pharmaceutical and nutraceutical industrial sectors of a society [2]. The diversity in wild plant species contributes to household food security and health $[3,4]$. There are over 20,000 species of wild edible plants in the world, yet fewer than 20 species now provide $90 \%$ of our food [5]. Evidence indicates that more than 300 million people throughout the contemporary world gain part or all of their livelihood and food from forests [6].

Wild edible plants play an important socio-economic role as medicines, dyes, poisons, shelter, fibers and religious and cultural ceremonies [7]. About $46 \%$ of world's poor live in South Asia [8] of which 75 million dwell Himalayas [9] and the biomass extraction is most widespread pressure on forests [10]. Despite agricultural societies' primary reliance on crop plants, the tradition of eating wild plants has not completely disappeared, because of their nutritional role and health benefits. However, consumption is determined less by calorie input and more by the pleasure of gathering wild resources, recreating traditional practices and enjoying characteristic flavors [11]. Both food and medicinal plants have interventional uses. Food can be used as medicine and vice versa.

Previous epidemiologic studies have consistently shown that diet plays a crucial role in the prevention of chronic diseases [12]. This convincing evidence suggests that a change in dietary behavior such as increasing consumption of fruit, vegetables, and grains is a practical strategy for significantly reducing the incidence of chronic diseases. Consumption of vegetables, as well as grains, has been strongly associated with reduced risk of cardiovascular disease, cancer, diabetes, Alzheimer disease, cataracts, and age-related functional decline [13-16]. The relationship between food and health becomes increasingly significant as consumers now demand healthy, tasty and natural functional foods that have been grown in uncontaminated environment [17]. Knowledge of such foods is a part of traditional knowledge which is mainly transmitted through contribution of individuals of households [18]. In many parts of the world the traditions of using wild edible plants as food and medicine are at risk of disappearing, hence it is of outmost importance to obtain data about popular uses of such plants species before this knowledge disappears $[19,20]$.

\section{Materials and methods}

\section{Study site description}

Present study was conducted from January 2010 to May 2012 in different sites of Lesser Himalayas. Data was collected from 85 localities of five major sampling sites including Abbottabad, Haripur, Mansehra districts of Khyber Pakhtunkhwa province (KPK), Margalla Hills National Park Islamabad, Murree Hills and its allied areas in the province of Punjab (Figure 1). The Himalaya range occupies in Pakistan the regions of Kashmir, Kaghan, Kohistan, Deosai and Chilas. The Lesser Himalaya is a prominent range 2,000 to 3,000 meters elevation and lies between $33^{\circ}-44^{\prime}$ and $35^{\circ}-35^{\prime}$ north latitude and between $72^{\circ}-33^{\prime}$ and $74^{\circ}-05^{\prime}$ east longitude. The total area of Lesser Himalayas in Pakistan is proximately $23295 \mathrm{~km}^{2}$ [21] and the total population is proximately 10 million [22]. Due to variation in the topography, altitudes aspects and vegetation cover, the climate of Lesser Himalayas ranges show tremendous variation. It falls into two major categories includes, Subtropical continental lowland including the plain and foot-hills zone and Subtropical continental highland including outer and middle Himalayas, Siwalik hills, Murree hills and entire Hazara hills. The average rainfall varies from $70-90 \mathrm{~mm}$ in southern parts whereas $100-130 \mathrm{~mm}$ in northern parts. A large part of the winter precipitation from the western disturbance is received in the form of snow. The northern parts receive little rain but heavy snowfall in the winter $[21,23]$. The vegetation of Lesser Himalaya falls within the subtropical, temperate, sub-alpine and alpine zones. The range management divided the area into six vegetation zones, namely; subtropical sub-humid zone, subtropical humid zone, temperate humid zone, sub alpine zone and glaciers or snow fields [21].

\section{Ethnobotanical study}

Ethnobotanical data was collected through well-versed semi-structured interviews, questionnaires, and focus group conversation with (125) key informants ranged from 15-70 years including farmers, herdsmen, shepherds, housewives, school boys and children having sound traditional knowledge of useful wild edible plants $[11,24]$. Adult female members from the household, accountable for food preparation, were considered as the key respondents with supplementary information from children and adults which facilitate in collection and processing of wild edible vegetables [18] and their answers were noted verbatim [25].

Questions about wild edible vegetables consumption were mainly focused on local name of plant, part/parts of the plants used, flowering period, place, season and quantity of collection, habitat, mode of preparation and consumption, medicinal uses (method of preparation, mode of application, diseases cured), other ethnobotanical uses as (fodder, fuel, ornamental purpose, fencing, 
construction etc.) and threats to wild edible vegetables. Authenticity of the claims was verified by cross checking of the collected data at different villages either by showing the fresh specimen, telling local names or showing field photographs to local informants.

A total of 45 wild edible vegetables were included in the present investigation based on their use in the study area. Taxonomic identification of the collected plant samples was carried out with the help of flora of Pakistan [26]. The plant specimens were properly pressed, dried and mounted on standard size of herbarium sheets. The voucher specimens were deposited in the Herbarium of Pakistan, Department of Plant Sciences, Quaid-i -Azam University, Islamabad.

\section{Cultural importance index $(\mathrm{Cl})$}

In order to find out cultural significance of each species in every locality cultural importance index (CI) was calculated as the summation of the use report (UR) in every use category mentioned for a species in the locality divided by number of participants $(\mathrm{N})$ in that locality.
Similarly mean cultural importance index (mCI) of each, specie was also deliberate [11]. The cultural significance of each family (CIf) was calculated by adding cultural importance index (CI) of the species from each family [27].

$$
C I=\sum_{i=1}^{i=N U} \frac{U R i}{N}
$$

\section{Threats to wild edible vegetables}

In order to know local peoples' awareness on various activities intimidating wild edible plants, a number of threatening factors like agricultural, over grazing, harvesting and fire were identified with the community [28]. The factors were presented to informants to choose from. Then the scores from each respondent summed up, the ranks determined and the factor that received the highest total score ranked first.

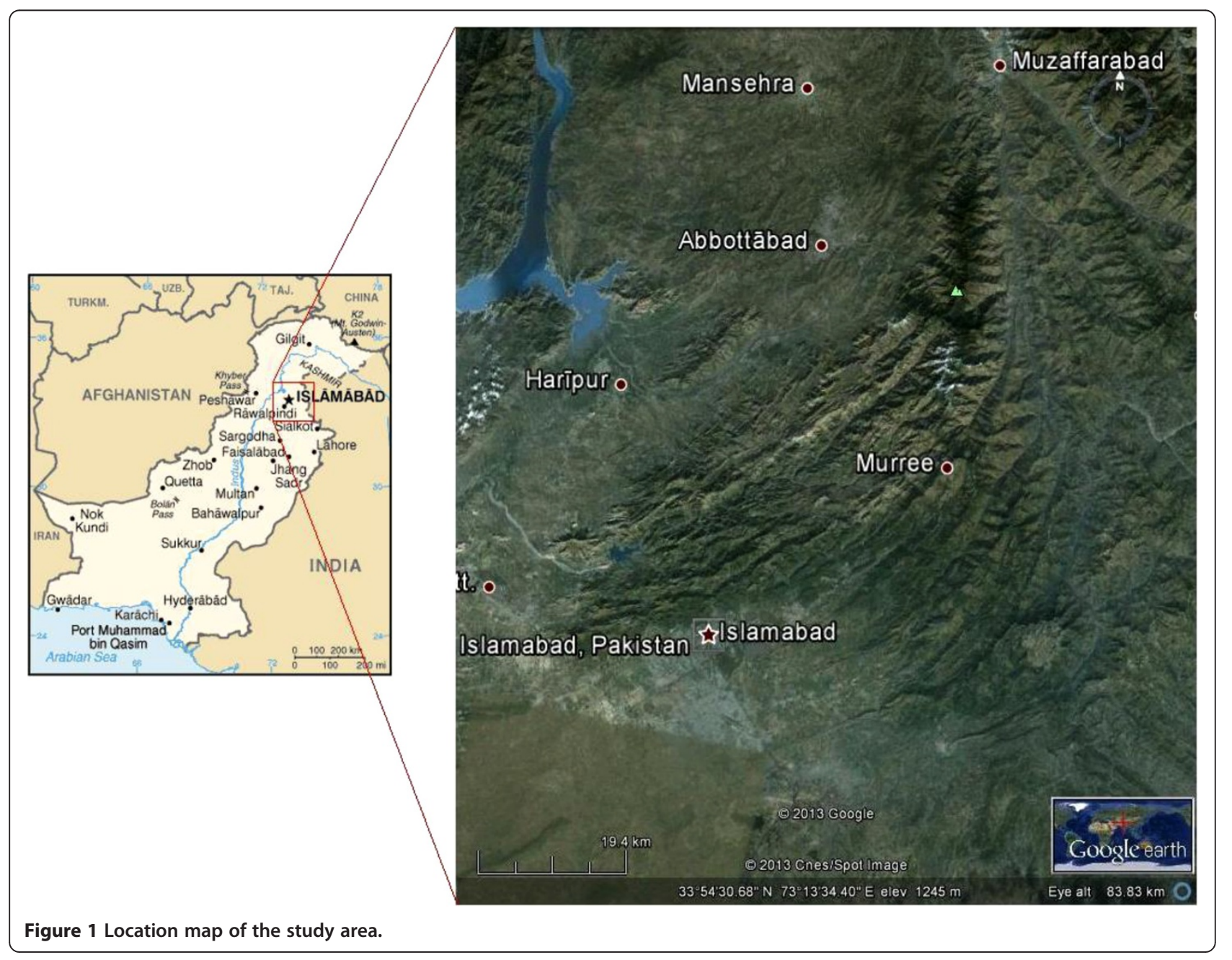




\section{Results and discussion}

\section{Taxonomic diversity}

Flora of Lesser Himalayas is a rich source of diverse useful plant species. A total of 45 wild edible vegetables belonging to 38 genera and 24 families are collected and consumed by the local inhabitants of the study areas as mentioned in Table 1. Asteraceae and Papilionoideae were observed dominating families with (6 spp. each), followed by Amaranthaceae and Polygonaceae (4 spp. each), whereas rest of the families were represented by 2 and one species. Growth forms indicated that herbs were dominating (89\%) followed by trees $(9 \%)$ and shrubs $(2 \%)$.

\section{Plant parts used and mode of consumption}

Different parts of wild edible vegetables were consumed in diverse ways according to local traditions (Table 1). Wild edible vegetables are cooked as fresh in water (51\%), e.g. Amaranthus spp. Digera muricata, Bidens bipinnata, Capsella bursa-pastoris, Nasturtium officinale, Stellaria media, Commelina benghalensis, Malva parviflora, Lathyrus aphaca, Medicago polymorpha, Melilotus spp. Vicia spp. Portulaca quardifida, Galium aprine, Solanum nigrum and Torilis leptophyll; in diluted milk (42\%) e.g. Cichorium intybus, Launaea procumbens, Sonchus spp. Taraxacum officinale, Bauhinia variegate, Silene conoidea, Tulip stellata, Plantago lanceoplata, Bistorta amplexicaulis, Pimpinella diversifolia, Ficus and Rumex species; and in both water and diluted milk (Lussii) (7\%) e.g. Ficus and Sonchus species. Flowers and rhizome of some vegetables species were also consumed fried in vegetable oil or ghee such as Bombax malabaracum and Dioscorea deltoidea. Present findings are in agreement to [19] regarding plants consumed cooked in several Mediterranean regions.

\section{Medicinal uses of wild edible vegetables species}

No one knows when or where plants first began to be used in the treatment of diseases, but the grave of a Neanderthal man buried 60,000 years ago, revealed that connection between plants and health has existed for thousands of years [29]. The northern mountains of Pakistan are well known for their biodiversity as they are located at the intersection of great Karakorum, Himalaya and Hindu Kush ranges. These three mountain ranges together contain 25,000 species (about $10 \%$ of the world floras), out of which around 10,000 are economically or medicinally useful. Estimated total flora of Pakistan is comprised of 6000 species, out of which more than 4000 plant species grow in mountainous regions of Hindukush and Himalayas [30,31]. Over $75 \%$ of population in Pakistan is cured by means of traditional medicines, prescribed by more than 50,000 traditional herb practitioners and the traditional knowledge of plant based medications pass down from family to family of herbalists and within communities [32].

During present survey decline was categorically observed in the trends of using conventional phytotherapies which is obviously because, the younger generation usually consider the belief in plant remedies a sort of superstition and less efficient compared to modern medicine. It was observed that leaves are highly utilized (70\%) plant parts followed by seeds (10\%), roots (6\%), latex (4\%), bark, bulb, flowers, tubers and rhizomes (2\% each). Data presented in (Table 1), revealed that a total 51 recipes based on wild edible vegetables were used by the inhabitants of study sites. These medications can be divided into two categories: single plant based and from more than one plant based medications. In majority of the cases water is used as medium for preparation while milk, ghee, oil, egg and butter are used for application which is corroborated with [33]. Modes of preparation falls into different categories (Figure 2), such as paste of plant parts (29\%) was common mode of recipes followed by decoction $(24 \%)$, powder $(14 \%)$, eaten fresh $(12 \%)$, extract $(10 \%)$, cooked vegetable (8\%) and juice (4\%). Mostly the mode of application falls in two categories topical as well as oral. Oral medications are taken along with water, milk or black tea. In regard to the patient condition, the preparations are applied more than two times each day until control.

The local inhabitants identified different types of ailments including gastrointestinal disorders (abdominal pain, gas trouble, gastric ulcer, intestinal worms, constipation, vomiting, diarrhea, dysentery), respiratory problems (asthma, flue, throat ache, cough), skin infections (measles, mouth gums, rashes, wound healing), bone fracture, rheumatism, diabetes, earache, tooth ache, eye infection, fever, heart problems, inflammation, jaundice, kidney problems, menstrual disorders, milk production, piles, scorpion sting and general weakness which were treated through different plant based remedies; twelve medications were used to cure gastrointestinal disorders followed by eleven to treat skin infections, ten against constipation, eight to cure rheumatism, four for each eye diseases, fever and jaundice, two for each inflammation, kidney problems and scorpion sting, where as other diseases were treated by one recipe each (Figure 3).

Medicinal uses of wild edible vegetables were compared with the available ethnobotanical literature which indicated that present applications of Cichorium intybus, Stellaria media, Launaea procumbens, Chenopodium album, Dioscorea deltoidea, Oxalis corniculata, Lathyrus aphaca, Vicia sativa, Plantago lanceoplata, Rumex dentatus, Rumex hastatus, Solanum nigrum, Pimpinella diversifolia and Torilis leptophylla were in agreement to [30,33-53]. Seed powder of Amaranthus hybridus, A. spinosus and $A$. viridis was used to improve eye vision 
Table 1 Medicinal values of wild edible vegetables of lesser Himalayas-Pakistan

\begin{tabular}{|c|c|c|c|c|}
\hline S. No & Botanical name/Family & Part used & Mode of preparation and application & Diseases cured \\
\hline \multirow[t]{2}{*}{1} & Amaranthus hybridus L. & \multirow[t]{2}{*}{ Seeds } & \multirow{2}{*}{$\begin{array}{l}\text { Dried seeds are grinded and powder is taken } \\
\text { orally with water. }\end{array}$} & \multirow[t]{2}{*}{ Eye vision } \\
\hline & Amaranthaceae & & & \\
\hline \multirow[t]{2}{*}{2} & Amaranthus spinosus L. & \multirow[t]{2}{*}{ Seeds } & \multirow[t]{2}{*}{ Dried seeds powder is taken orally with water. } & \multirow[t]{2}{*}{ Eye vision } \\
\hline & Amaranthaceae & & & \\
\hline \multirow[t]{2}{*}{3} & Amaranthus viridis $\mathrm{L}$. & Seeds & Dried seeds powder is taken orally with water. & Eye vision \\
\hline & Amaranthaceae & Roots & Fresh roots are crushed and paste is applied topically & Scorpion sting \\
\hline \multirow[t]{2}{*}{4} & Digera muricata L. & \multirow[t]{2}{*}{ Leaves } & \multirow{2}{*}{$\begin{array}{l}\text { Fresh leaves are cooked in water and paste } \\
\text { is taken orally. }\end{array}$} & \multirow[t]{2}{*}{ Constipation } \\
\hline & Amaranthaceae & & & \\
\hline \multirow[t]{2}{*}{5} & $\begin{array}{l}\text { Dryopteris ramosa (Hope) } \\
\text { C. Chr. }\end{array}$ & \multirow[t]{2}{*}{ Leaves } & \multirow[t]{2}{*}{ Leaves are cooked as vegetable and taken orally. } & \multirow[t]{2}{*}{ Gastric ulcer, constipation } \\
\hline & Aspidiaceae & & & \\
\hline \multirow[t]{2}{*}{6} & Bidens bipinnata $\mathrm{L}$. & \multirow[t]{2}{*}{ Leaves } & \multirow[t]{2}{*}{ Fresh leaves extract is applied topically. } & \multirow[t]{2}{*}{ Leprosy and skin cuts } \\
\hline & Asteraceae & & & \\
\hline \multirow[t]{2}{*}{7} & Cichorium intybus L. & \multirow[t]{2}{*}{ Leaves } & \multirow[t]{2}{*}{ Fresh leaves decoction is taken orally } & \multirow{2}{*}{$\begin{array}{l}\text { Fever, gas trouble, } \\
\text { and body swelling }\end{array}$} \\
\hline & Asteraceae & & & \\
\hline \multirow[t]{2}{*}{8} & $\begin{array}{l}\text { Launaea procumbens (Roxb.) } \\
\text { Ramayya \& Rajagopal }\end{array}$ & \multirow[t]{2}{*}{ Leaves } & $\begin{array}{l}\text { Fresh leaves are grinded along with sugar and } \\
\text { extract is taken orally }\end{array}$ & Painful micturation \\
\hline & Asteraceae & & & \\
\hline 9 & Sonchus asper L. & Leaves & Leaves decoction is taken orally & Fever, constipation \\
\hline & Asteraceae & & & \\
\hline 10 & Sonchus oleraceous L. & Leaves & Fresh leaves decoction is taken orally & Body weakness, constipation \\
\hline & Asteraceae & & & \\
\hline 11 & Taraxacum officinale L. & Rhizome & Fresh rhizomes decoction is taken orally & Jaundice \\
\hline & Asteraceae & & & \\
\hline 12 & $\begin{array}{l}\text { Bombax malabaracum (DC.) } \\
\text { Schott \& Endlicher }\end{array}$ & Bark & Fresh bark is crushed and past is applied topically & $\begin{array}{l}\text { Skin eruptions, pimples, } \\
\text { joint pain }\end{array}$ \\
\hline & Bombacaceae & & & \\
\hline 13 & Capsella bursa-pastoris (L.). & Leaves & Fresh leaves decoction is taken orally & Menstrual disorder \\
\hline & Medic Brassicaceae & & & \\
\hline 14 & $\begin{array}{l}\text { Nasturtium officinale R.Br. } \\
\text { Brassicaceae }\end{array}$ & Leaves & $\begin{array}{l}\text { Fresh leaves are cooked as vegetables and taken } \\
\text { orally }\end{array}$ & Constipation \\
\hline 15 & $\begin{array}{l}\text { Bauhinia variegate } L . \\
\text { Caesalpiniodeae }\end{array}$ & $\begin{array}{l}\text { Leaves, } \\
\text { flowers }\end{array}$ & Leaves and flowers paste is give to cattle & Diarrhoea \\
\hline 16 & $\begin{array}{l}\text { Silene conoidea } \mathrm{L} \text {. } \\
\text { Caryophyllaceae }\end{array}$ & Leaves & Fresh leaves paste is applied topically & Skin infection \\
\hline 17 & Stellaria media (L.). Cyr. & Leaves & Fresh leaves paste is applied topically & Swelling joints, broken bones \\
\hline & Caryophyllaceae & & Fresh leaves decoction is taken orally & Constipation \\
\hline 18 & Chenopodium album $\mathrm{L}$. & Leaves & Fresh leaves are cooked as vegetable and eaten raw. & Constipation, intestinal worms \\
\hline & Chenopodiaceae & & $\begin{array}{l}\text { Fresh leaves are grinded and mixed with water and } \\
\text { sugar. This juice is taken orally }\end{array}$ & Jaundice, urinary disorder \\
\hline 19 & Commelina benghalensis $\mathrm{L}$. & Roots & Dried roots are grinded and powder is taken orally & Epilepsy \\
\hline & Commelinaceae & & Fresh roots decoction is taken orally & Stomach disorders \\
\hline 20 & Evolvulus alsinoides L. & Leaves & Leaves are crushed and mixed along with water. & Indigestion, constipation \\
\hline & Convolvulaceae & & & \\
\hline 21 & $\begin{array}{l}\text { Dioscorea deltoidea Wall. ex, } \\
\text { Kunth. }\end{array}$ & Tubers & $\begin{array}{l}\text { Tubers are crushed and paste is taken } \\
\text { orally and topically }\end{array}$ & Intestinal worms and lice \\
\hline
\end{tabular}

Dioscoreaceae 
Table 1 Medicinal values of wild edible vegetables of lesser Himalayas-Pakistan (Continued)

\begin{tabular}{|c|c|c|c|c|}
\hline 22 & $\begin{array}{l}\text { Lamium amplexicaule L. } \\
\text { Lamiaceae }\end{array}$ & Leaves & Fresh leaves paste is applied topically & Joints swelling \\
\hline 23 & $\begin{array}{l}\text { Origanum vulgare subsp. Hirtum } \\
\text { L. }\end{array}$ & Leaves & Fresh leaves are chewed & Toothache and mouth gums \\
\hline & Lamiaceae & & & \\
\hline 24 & $\begin{array}{l}\text { Tulip stellata var. clusiana Hk. f., } \\
\text { Liliaceae }\end{array}$ & Bulbs & Fresh bulbs are pealed off and taken orally & Heart problem \\
\hline 25 & $\begin{array}{l}\text { Malva parviflora L. } \\
\text { Malvaceae }\end{array}$ & Leaves & Fresh leaves decoction is taken orally & Constipation, cough, fever \\
\hline 26 & Ficus carica $\mathrm{L}$. & Leaves & Fresh leaves are crushed and paste is applied topically & Boils \\
\hline & Moracea & Latex & Fresh milky latex is applied topically & Watts \\
\hline 27 & Ficus palmata Forssak. & Leaves & $\begin{array}{l}\text { Fresh leaves are boiled in the milk of goat and taken } \\
\text { orally }\end{array}$ & Bowel complaints \\
\hline & Moracea & Latex & Milky latex is applied topically & Warts, small tumours \\
\hline 28 & $\begin{array}{l}\text { Oxalis corniculata L. } \\
\text { Oxalidaceae }\end{array}$ & Leaves & Fresh leaves are crushed and paste is applied topically & Worms and scorpion sting \\
\hline 29 & $\begin{array}{l}\text { Lathyrus aphaca L. } \\
\text { Papilionoideae }\end{array}$ & Seeds & Dried seeds powder is mixed in tobacco & Narcotic, soothing effect \\
\hline 30 & $\begin{array}{l}\text { Medicago polymorpha L. } \\
\text { Papilionoideae }\end{array}$ & Leaves & Fresh leaves are cooked in water and taken orally & Constipation, indigestion \\
\hline 31 & $\begin{array}{l}\text { Melilotus albus Medik. } \\
\text { Papilionoideae }\end{array}$ & Leaves & Fresh leaves paste is applied topically & Inflammation, joint pain \\
\hline 32 & $\begin{array}{l}\text { Melilotus indicus (L.) } \\
\text { All. Papilionoideae }\end{array}$ & Leaves & Fresh leaves paste is applied topically & Joint swelling \\
\hline 33 & $\begin{array}{l}\text { Vicia faba L. } \\
\text { Papilionoideae }\end{array}$ & Leaves & Fresh leaves decoction is taken orally & Kidney pain, eye infection \\
\hline 34 & $\begin{array}{l}\text { Vicia sativa L. } \\
\text { Papilionoideae }\end{array}$ & Leaves & Leaves paste is applied topically & Scorpion sting \\
\hline 35 & $\begin{array}{l}\text { Plantago lanceolata } \mathrm{L} . \\
\text { Plantaginaceaea }\end{array}$ & $\begin{array}{l}\text { Leaves } \\
\text { Seed husk }\end{array}$ & $\begin{array}{l}\text { Fresh leaves paste is applied topically } \\
\text { Seed husk along with sugar (Gur) is mixed in water } \\
\text { and taken orally }\end{array}$ & $\begin{array}{l}\text { Sores } \\
\text { Jaundice, internal body } \\
\text { inflammation, constipation }\end{array}$ \\
\hline 36 & $\begin{array}{l}\text { Polygonum amplexicaule D. Don, } \\
\text { Prodr. } \\
\text { Polygonaceae }\end{array}$ & Leaves & $\begin{array}{l}\text { Fresh leaves are boiled in water along with sugar and } \\
\text { decoction is taken orally }\end{array}$ & Fever, joint pain, flue \\
\hline 37 & $\begin{array}{l}\text { Polygonum aviculare L. } \\
\text { Polygonaceae }\end{array}$ & Leaves & Fresh leaves decoction is taken orally & Diarrhoea, dysentery \\
\hline 38 & $\begin{array}{l}\text { Rumex dentatus L. } \\
\text { Polygonaceae }\end{array}$ & Leaves & Fresh leaves are applied topically & Stinging nettle. \\
\hline 39 & $\begin{array}{l}\text { Rumex hastatus D. Don, Prodr. } \\
\text { Polygonaceae }\end{array}$ & $\begin{array}{l}\text { Leaves and } \\
\text { roots }\end{array}$ & $\begin{array}{l}\text { Fresh leaves are roots are crushed and mixed in } \\
\text { water. This extract is taken orally }\end{array}$ & Jaundice \\
\hline 40 & $\begin{array}{l}\text { Portulaca quadrifida L. } \\
\text { Portulaceaea }\end{array}$ & Leaves & Fresh leaves are slightly wormed and applied topically & Joint swelling \\
\hline 41 & $\begin{array}{l}\text { Galium aparine L. } \\
\text { Rubiaceae }\end{array}$ & Leaves & $\begin{array}{l}\text { Fresh leaves paste is applied topically } \\
\text { Extract of fresh leaves is taken orally. }\end{array}$ & $\begin{array}{l}\text { Wounds healing } \\
\text { Jaundice }\end{array}$ \\
\hline 42 & Veronica arvensis L. & Leaves & Fresh leaves decoction is taken orally & Skin infection, blood purifier \\
\hline
\end{tabular}

Scrophulariaceae 
Table 1 Medicinal values of wild edible vegetables of lesser Himalayas-Pakistan (Continued)

\begin{tabular}{|c|c|c|c|c|}
\hline 43 & $\begin{array}{l}\text { Solanum nigrum L. } \\
\text { Solanaceae }\end{array}$ & Leaves & $\begin{array}{l}\text { Leaves are crushed and mixed in water. This extract is } \\
\text { applied topically }\end{array}$ & Washing painful eyes \\
\hline \multirow[t]{2}{*}{44} & $\begin{array}{l}\text { Pimpinella diversifolia (Wall.) DC. } \\
\text { Prodor. }\end{array}$ & \multirow[t]{2}{*}{ Leaves } & \multirow[t]{2}{*}{$\begin{array}{l}\text { Dried leaves are grinded along with salt and powder } \\
\text { is taken orally }\end{array}$} & \multirow[t]{2}{*}{ Gas trouble, indigestion } \\
\hline & Umbelliferae & & & \\
\hline \multirow[t]{2}{*}{45} & Torilis leptophylla (L.) & \multirow[t]{2}{*}{ Leaves } & \multirow[t]{2}{*}{ Dried leaves powder is taken orally with water } & \multirow[t]{2}{*}{ Gastrointestinal disorders } \\
\hline & Reichb.f. Umbelliferae & & & \\
\hline
\end{tabular}

problems, whereas according to $[53,54]$ leaves of Amaranthus hybridus were used for internal inflammation, headache, stomach pain and to antidote snake and scorpion sting. Leaves of Amaranthus viridis and $A$. spinosus were found effective against scorpion sting, skin infections, mouth gums, piles, tooth ache diarrhoea and as laxative $[43,47,52,55,56]$. Extract from the leaves of Bidens bipinnata is used to cure leprosy and skin cuts, while same species was reported against stomach problems, menstruation, pain, influenza, scurvy, rheumatism, diarrhoea and for cold [44,53,57]. Leaf decoction of Sonchus asper and S. oleraceous are used against constipation and for body weakness, whereas [42,53] documented that leaves of $S$. oleraceous were effective against internal inflammation and wound healing. According to $[44,45,48,55,58]$ leaves of $S$. asper were found useful for stomach problems and Jaundice.

Decoction of Taraxacum officinale rhizome is used to cure jaundice, whereas $[41,52]$ mentioned that same species is used as aperients, diuretic, tonic, to cure constipation, kidney and liver disorders. Medicinal uses of
Bombax malabaracum were found similar to that of reported by $[30,33,57]$. Local inhabitants of Lesser Himalayas use leaf decoction of Capsella bursa-pastoris to cure menstrual disorders, whereas [57] reported that same species was effective for heat cleaning. Leaves of Nasturtium officinale were found effective against constipation, but $[53,55]$ mentioned that leaves and stem of same species were used to cure hepatic pain, pneumonia, indigestion, kidney pain and to purify blood. Paste form leaves and flowers of Bauhinia variegata was found useful to control diarrhoea, whereas [52] documented that bark of the same plant was used to treat skin diseases. The leaf paste of Silene conoidea was used against skin infections, but [38] mentioned that leaf paste of same species was used to cure pimples and backache.

Tribal communities of Himalayas use roots of Commelina benghalensis to cure epilepsy and stomach disorders, whereas [54] documented that leaves of the same species were found effective against liver complaints, snake and scorpion sting. Juice extracted from the leaves of Evolvulus alsinoides was found effectual

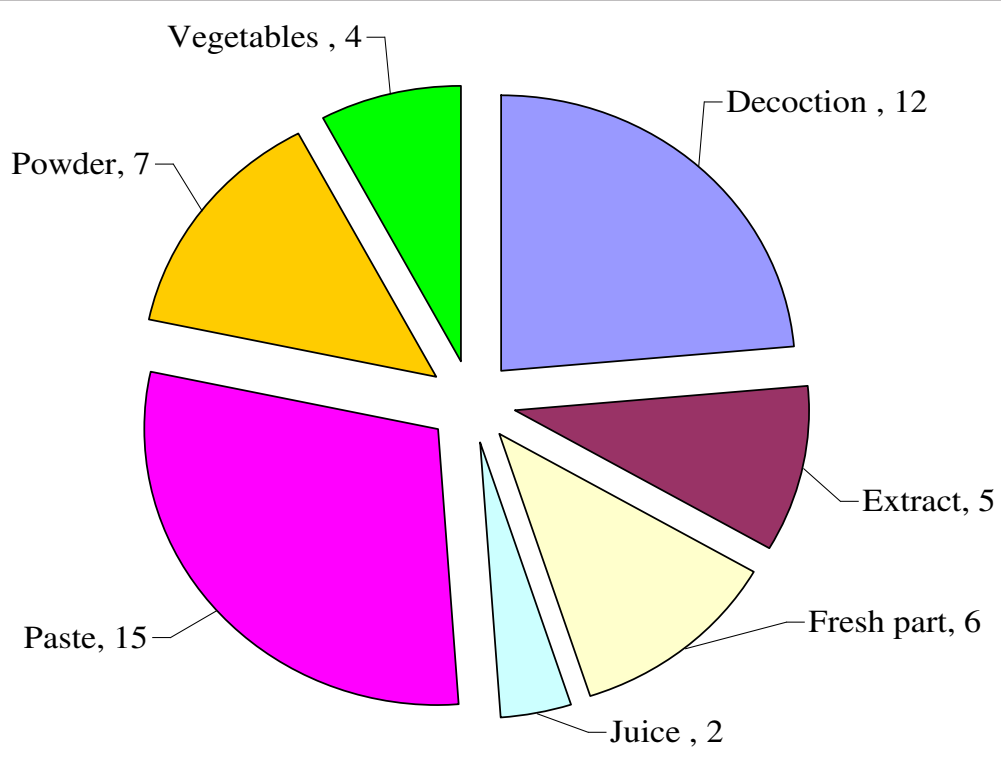

Modes of preparation (Vegetables)

Figure 2 Modes of preparation. 


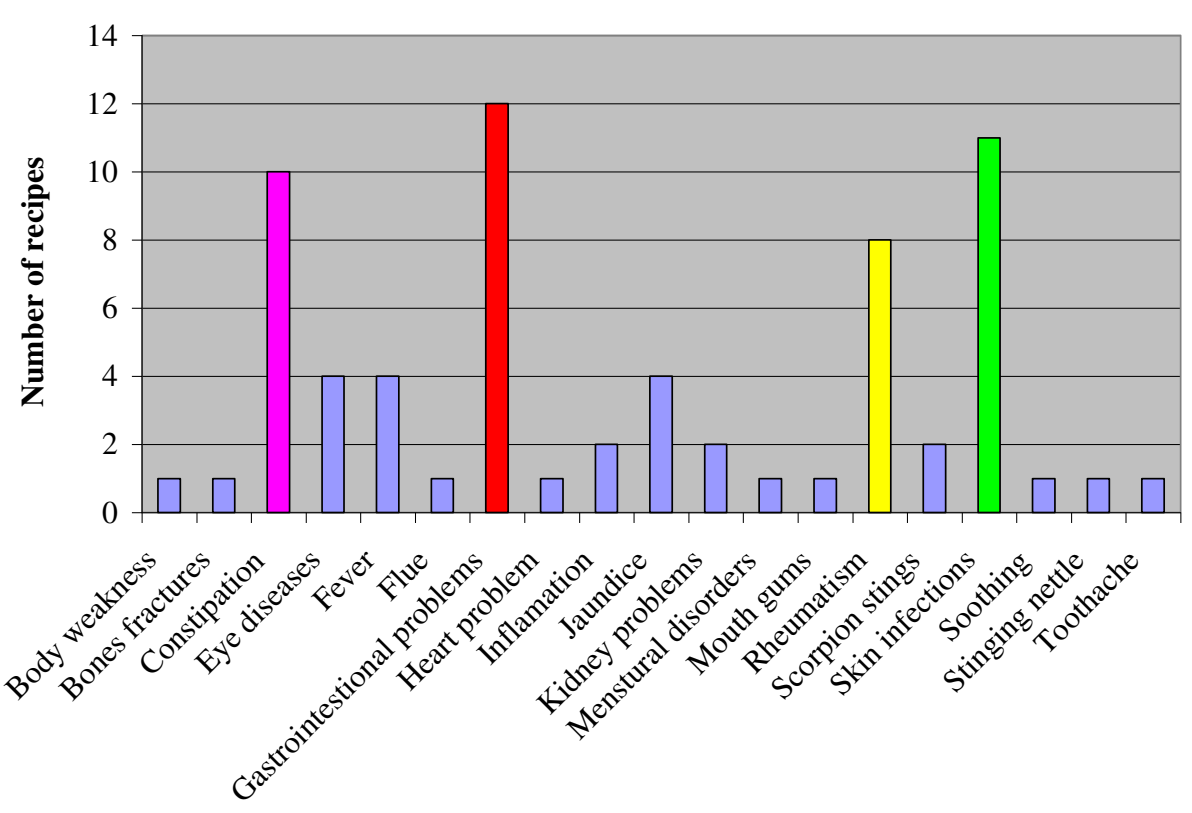

Disease cured (Vegetables)

Figure 3 Number of recipes anddiseases cured by wild vegetables species.

against constipation and indigestion, whereas [47] recognized that leaves of this species were used against asthma and bronchitis. Leaves of Origanum vulgare were used to cure mouth gums and toothache, while according to $[4,52]$ same species is used to alleviate stomach problems and sore throat. Leaf decoction of Malva parviflora was used to treat constipation, cough and fever, but according to [56] same plant is applied on swellings wounds and sores. Leaf paste and milky latex of Ficus carica and F. palmata were used to cure boils, warts, tumours and bowel complaints, whereas fruits of these species were found laxative [52,59]. Leaf decoction of Polygonum amplexicaule was found effective against fever, joint pain and flue; whereas [40] reported that leaves and shoots of same species were used for curing ulcer, sore throat, inflammation of mouth and tongue.

Fresh leaves of Portulaca quadrifida were applied topically on swelling joints, but according to [60] whole plant was used to cure asthma. Leaf paste and extract of Galium aparine were found effective for wound healing and jaundice, whereas [61] recognized that same species was used to cure injuries, skin infections, as tonic and diuretic. To our knowledge medicinal uses of Digeramuricata, Dryopteris ramosa, Lamium amplexicaule, Tulipa stellata, Medicago polymorpha, Melilotus albus, Melilotus indicus, Vicia faba, Polygonum aviculare and Veronica arvensis documented during present work were found hardly ever reported in adjacent areas and other parts of the world.

\section{Ethnobotanical uses of wild edible vegetables}

Among wild edible vegetables 43 species (95\%) were used as fodder and forage for life stock, 4 species (9\%) were used as fuel, 3 species each (7\%) of wild vegetables such as Ficus carica, F. palmata and Bauhinia variegata were used by the local inhabitants of Lesser Himalayas in making shelters, in fencing and hedging, as ornamental plant and for miscellaneous purpose, 2 species (4\%) were used in making tools handles and furniture (Figure 4). Ethnobotanical uses of wild edible vegetables reported during present investigation were found in agreement to $[30,35,39,55]$.

\section{Species' cultural importance}

The terms "cultural importance" and "relative importance" usually are used interchangeably in the literature to refer to the importance of certain plants to a given culture [62]. The cultural importance index (CI) explains not only the spread of the uses (number of informants) for each species, but also it's worth [63]. It can be assumed that the CI index is a proficient tool for highlighting those species with a high-agreement for the survey culture and so to recognize the shared knowledge of the peoples. During present study CI index and mean cultural importance index were computed to measure the cultural values of each wild edible vegetable in five studied sites [Additional file 1: Table S1], which can be used to evaluate the plant awareness between diverse cultures [11] and to study the intra cultural variations. On the bases of use reports (UR) the cultural importance index 


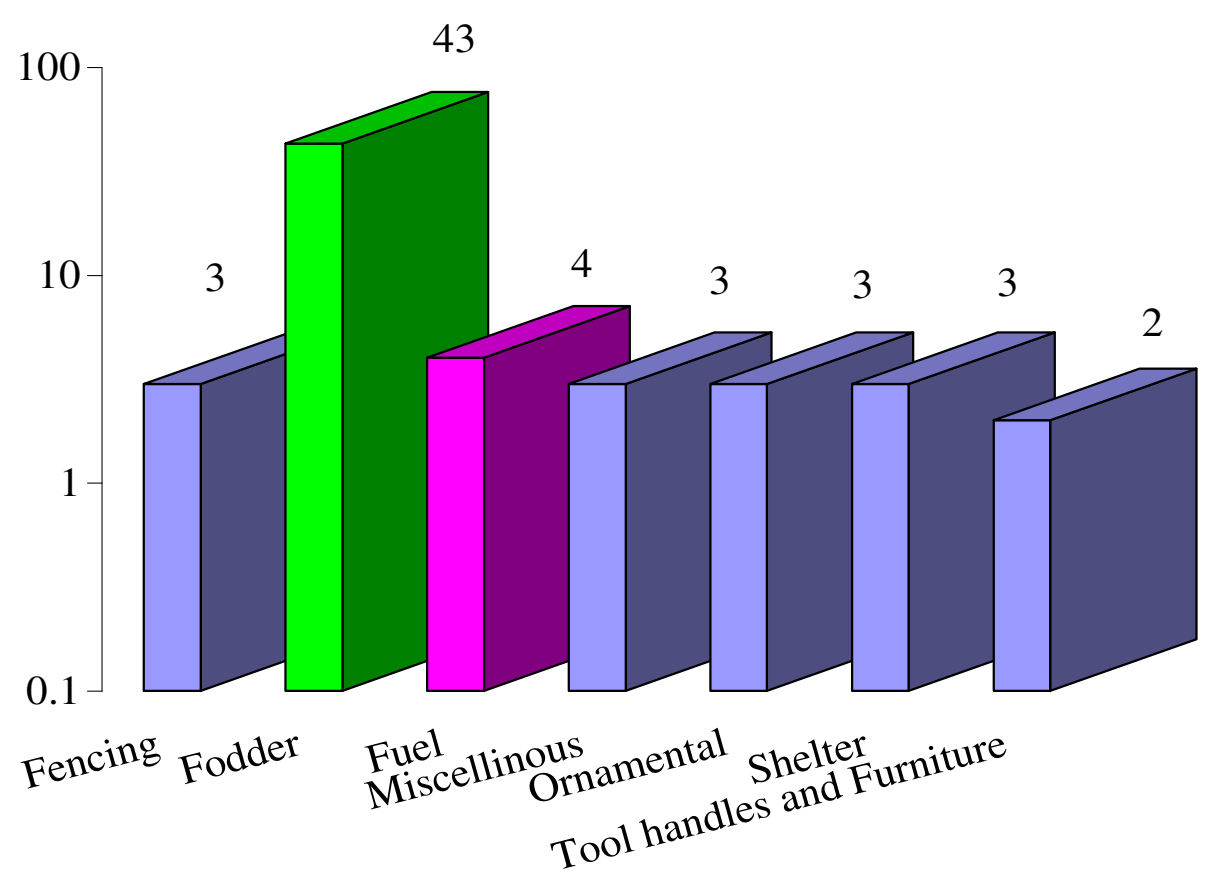

\section{Ethnobotanical use categories (Vegetables)}

Figure 4 Ethnobotanical use categories and their number.

(CI) and mean cultural index (mCI) of wild edible vegetables within the five study localities (Margalla Hills, Haripur, Abbottabad, Murree and Mansehra) of Lesser Himalayas were intended. Among all wild edible vegetables Ficus carica was found most cited species followed by Ficus palmata, Bauhinia variegata, Solanum nigrum, Amaranthus viridis, Medicago polymorpha, Chenopodium album, Cichorium intybus, Amaranthus hybridus and Vicia faba (Figure 5). All These species are used as food, medicines, fodder, as fuel wood, in construction, sheltering, fencing and making agricultural tools. Some of these plants are considered as holy plants being mentioned in holy books (e.g., Ficus carica and Ficus palmata in Quraan). It was also observed that because of cultural values or decision, local inhabitants use only a small part of their natural flora present in their surrounding.

\section{Difference in cultural index $(\mathrm{Cl})$ values for species among the different sites}

Results of cultural importance index and mean cultural importance index of 45 wild edible vegetables mentioned in descending order (Additional file 1: Table S1) confirmed substantial differences among the $\mathrm{CI}$ values obtained in the different areas. The top ten species of wild edible vegetables with the highest $\mathrm{mCI}$, were cited in all the five surveyed areas and most were important in every site. The next thirty two species were also used at all studied regions, Vicia sativa, Lamium amplexicaule. These are based on a common cultural background. Interestingly CI values for wild edible vegetables species in Margalla Hills (50.30) and district Haripur (44.26) were found higher than for species in other areas (Additional file 1: Table S1). These findings exhibited that the traditional knowledge of wild edible plants and plant collection are much spread in isolated areas compare to urban sites [11]. To scrutinize this further we can calculate the mean of the $\mathrm{CI}$ values for all the species in each study site (mCla) as a measure of botanical knowledge. It was found that mCIa value for Margalla Hills (1.117) was more than that of the values: 0.983 for Haripur, 0.774 for Mansehra, 0.693 for Abbottabad and 0.486 for Murree. This shows a great difference in the traditional knowledge of wild edible plants among different human groups. Although Mansehra, Abbottabad and Murree are adjoining and share similar environment, the difference is noteworthy and might be due to loss of knowledge in the former. Moreover high mCIa values in the isolated areas of Margalla Hills, Haripur and Mansehra indicates more dependence of inhabitants on surrounding natural flora.

\section{Cultural importance of the families}

A comparison between the cultural indexes of most quoted families (CIf) of wild edible vegetables mentioned in (Figure 6) revealed that Papilionoideae, with 


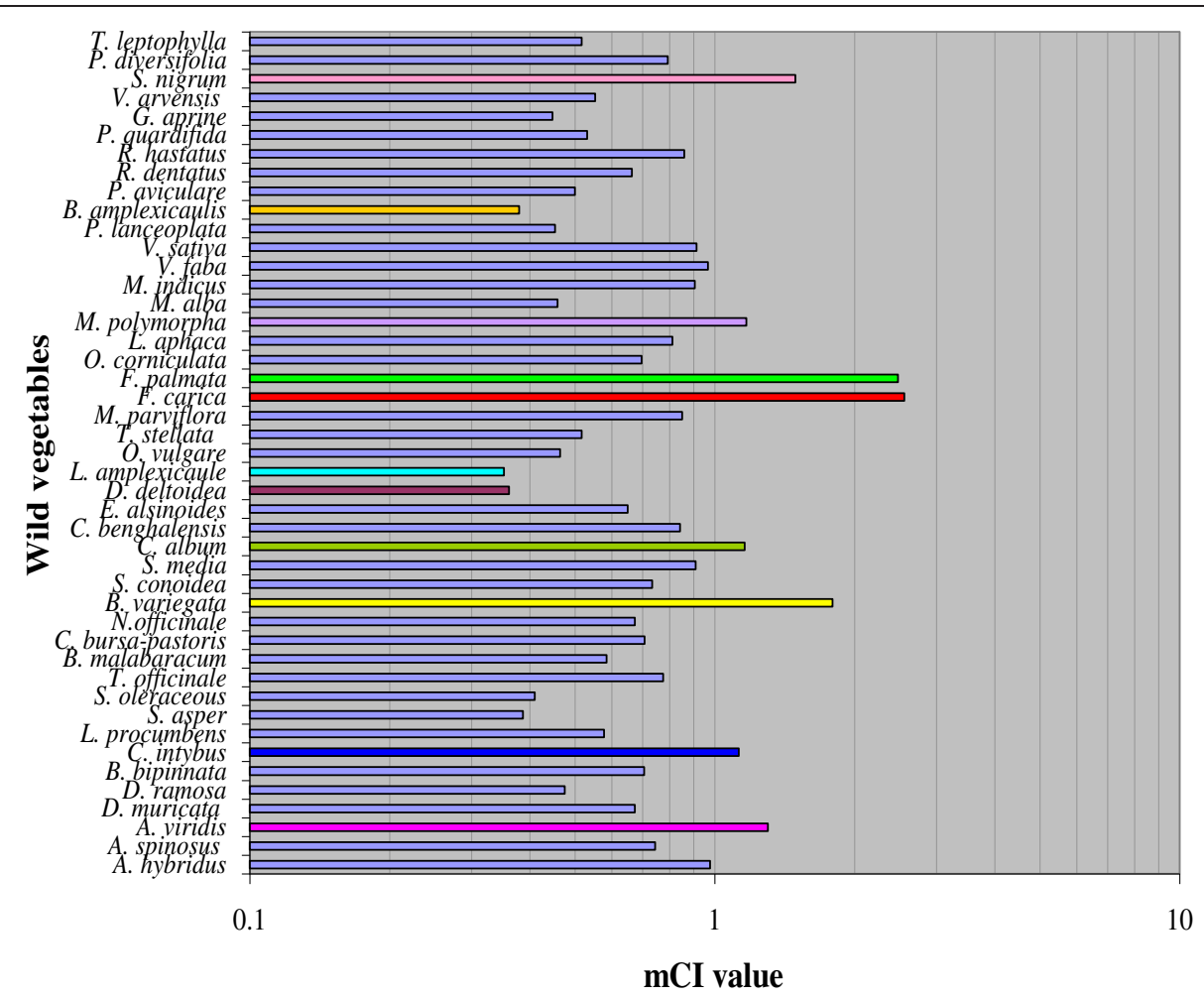

Figure 5 Mean cultural index of wild edible vegetables.

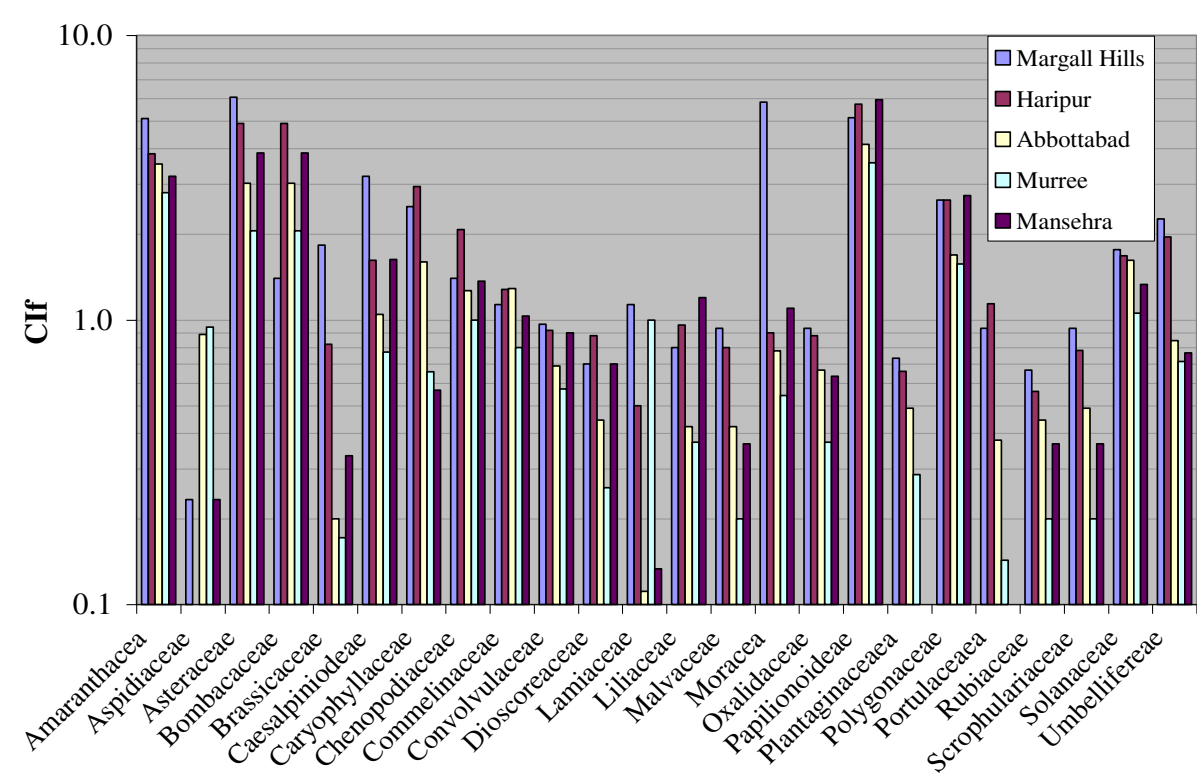

Families

Figure 6 Cultural importance index of wild edible vegetables' families (CIf). 
six species was found most quoted botanical family because members of this family were consumed as food, fodder and in medicines. Other remarkable families of wild vegetables within top ten were Asteraceae with six species, being consumed as vegetables and in medicines, followed by Amaranthaceae (4 species), Bombacaceae (1 species), Moraceae (2 species), Polygonaceae (4 species), Caesalpiniodeae (1 species), Caryophyllaceae (2 species), Solanaceae and Chenopodiaceae (1 species each). Remaining families of vegetables showed low representation and ethno-medicinal values. Present findings are in agreement with those of [19], who recognized that Asteraceae, Rosaceae and Umbelliferae were among the most significant families of wild edible plants in the Mediterranean regions. Hence present results confirm that local people tend to use preferably the plants that are accessible to them. These observations corroborated with those of [64-67].

\section{Socio-economic significance}

Income derived from the sale of wild plant species is very important for poor households in order to meet basic needs [28]. In addition to food and therapeutic values, some of the studied species are also marketable and provide the chance of additional household income. During present survey it was observed that $17.7 \%$ of wild edible vegetables e.g., Dryopteris ramosa, Nasturtium officinale, Bauhinia variegata, Chenopodium album, Malva parviflora, Portulaca quardifida and Solanum nigrum were soled as vegetables at local markets of Abbottabad, Rawalpindi and Haripur (Additional file 2: Table S2), 0.04\% e.g., Ficus carica, Ficus palmata are marketed as edible fruits and $0.06 \%$ e.g., Bauhinia variegata, Ficus carica and Ficus palmata are soled as fuel wood locally.

\section{Threats to wild edible plants}

Present investigation revealed that mostly wild edible vegetables are collected from waste lands (44.5\%), agricultural fields (33.4\%), forests (20\%) and water bodies (2.2\%). These plant species were found under threats in their natural habitats because of different human activities. According to local inhabitants agricultural land expansion, over-harvesting, over-grazing, uncontrolled fire setting and fuel wood collection are among the common threats to these alternative food resources and their impacts varies from place to place. In order to find out local inhabitants perception on threats to wild edible vegetables, pair wise ranking of five factors (agricultural land expansion, over-harvesting, over-grazing, uncontrolled fire setting and fuel wood collection) were conducted.

However, the overall rating for all communities mentioned in Table 2, demonstrated agricultural land expansion as the dominating threat to wild edible vegetables, followed by over-harvesting, over-grazing, fire and fuel wood collection. Majority of the wild edible vegetables have no protection except, Bauhinia variegata, Chenopodium album, Solanum nigrum, Ficus carica and Ficus palmata which are protected, cultivated and marketed by some formers. This shows that achievement of economic payback from plant species might endorse local people's interest in the conservation, maintenance and preservation of significant and endangered species [28].

\section{Conclusion}

Major populace of Lesser Himalayas still use wild edible plants as food and to cure various ailments but, this traditional knowledge have severely eroded due to change in the life style of local inhabitants, which needs to be documented before it is too late. Present investigation revealed that patterns of wild edible plant usage depend mainly on socio-economic factors compare to climatic conditions or wealth of flora. Analysis of results indicated that in all the surveyed areas, most of the plants are consumed by poor families during normal and difficult times. However, decline in use of some species may lead to the diminishing of the traditional knowledge about such plants. Use reports and citation of majority of wild edible vegetables, confirmed a universal cultural heritage in the study sites regarding the gathered food plants, because most of the quoted taxa are same and

Table 2 Pair wise ranking of factors considered as threats to wild edible vegetables

\begin{tabular}{|c|c|c|c|c|c|c|c|c|c|c|c|c|c|c|c|c|c|c|c|c|c|c|}
\hline \multirow[t]{3}{*}{ Factors } & \multicolumn{20}{|c|}{ Respondents } & \multirow[t]{3}{*}{ Total } & \multirow[t]{3}{*}{ Rank } \\
\hline & $\overline{\mathrm{MH}^{*}}$ & MH & $\mathrm{MH}$ & MH & $\mathrm{H}^{*}$ & DH & $\mathrm{DH}$ & $\mathrm{DH}$ & $A B^{*}$ & $A B$ & $A B$ & $A B$ & $\mathrm{Mu}^{*}$ & $\mathrm{Mu}$ & $\mathrm{Mu}$ & $\mathrm{Mu}$ & $\mathrm{Mn}^{*}$ & $\mathrm{Mn}$ & $M n$ & $\mathrm{Mn}$ & & \\
\hline & 1 & 2 & 3 & 4 & 1 & 2 & 3 & 4 & 1 & 2 & 3 & 4 & 1 & 2 & 3 & 4 & 1 & 2 & 3 & 4 & & \\
\hline Agricultural land expansion & 4 & 3 & 2 & 3 & 6 & 5 & 3 & 7 & 3 & 4 & 2 & 1 & 3 & 2 & 3 & 3 & 4 & 2 & 3 & 2 & 65 & 1 \\
\hline Over harvesting & 2 & 3 & 2 & 3 & 3 & 4 & 2 & 4 & 2 & 1 & 3 & 2 & 1 & 3 & 1 & 4 & 3 & 1 & 2 & 4 & 50 & 2 \\
\hline Over grazing & 1 & 3 & 1 & 2 & 2 & 1 & 3 & 1 & 1 & 2 & 1 & 3 & 2 & 1 & 3 & 1 & 2 & 3 & 1 & 2 & 36 & 3 \\
\hline Fire & 3 & 2 & 4 & 1 & 3 & 2 & 1 & 2 & 1 & 1 & 0 & 1 & 2 & 1 & 1 & 2 & 1 & 0 & 2 & 1 & 31 & 4 \\
\hline Fuel & 2 & 1 & 0 & 2 & 1 & 2 & 0 & 1 & 3 & 1 & 1 & 0 & 1 & 2 & 1 & 0 & 0 & 1 & 1 & 0 & 20 & 5 \\
\hline
\end{tabular}

${ }^{*} \mathrm{MH}$ Margalla Hills National Park, ${ }^{*} \mathrm{H}$ Haripur, ${ }^{*} \mathrm{AB}$ Abbottabad, ${ }^{*} \mathrm{Mu}$ Murree, ${ }^{*}$ Mn Mansehra. The score mentioned in the table is based on the information from 16 key informants at four sub sites from each study area. 
their cultural worth is analogous. However, a few differences in the cultural importance indices of wild edible vegetables were also observed, which may be due to the similar live hood and difference in indigenous knowledge of the local communities. Ficus carica, Ficus palmata, Bauhinia variegata and Solanum nigrum exhibited maximum cultural importance index (CI). Present findings also revealed that many wild edible vegetables species are under pressure from various anthropogenic factors, demand public awareness, community based management and urgent collection of germplasm. Further exploration is suggested into nutritional profile, phytochemical analysis, antioxidant potential, essential and toxic components in conventional food resources; pharmacological applications; dietary requirements; skill training in farming and biotechnological techniques to improve yields.

\section{Additional files}

Additional file 1: Table S1. Cultural important index (Cl), mean cultural importance index $(\mathrm{mCl})$ of wild edible vegetables.

Additional file 2: Table S2. Socio-economic values of wild edible vegetables.

\section{Competing interests}

The authors declare that they have no competing interests.

\section{Authors' contribution}

a) AMA: Present paper is a part of my PhD work, I have Carried out field survey, sampling, data collection and compilation of manuscript. b) MAK: Supervised the work. c) MHS: Supervised the work and technical checking the manuscript. d) MMS: Help in field work and Moral Support. e) AP: Support in data collection. f) MA: Plants identification. All authors read and approved the final manuscript, there is no objection or further suggestion.

\section{Acknowledgements}

The financial assistance provided by Higher Education Commission (HEC) of Pakistan to carry out this project is gratefully acknowledged. We are also thankful to the local inhabitants and herbalists for their assistance and providing required information.

\section{Author details}

'Department of Environmental Sciences, COMSATS Institute of Information Technology, Abbaottabad, Pakistan. ${ }^{2}$ Department of Plant Sciences, Quaid-i-Azam University, Islamabad 45320, Pakistan. ${ }^{3}$ Department of Chemistry, Quaid-i-Azam University, Islamabad 45320, Pakistan.

Received: 16 July 2013 Accepted: 13 September 2013

Published: 14 September 2013

\section{References}

1. Ahmad H: Issues Regarding Medicinal Plants of Pakistan. Udy Today 1999, 6(3):6-7.

2. Pei SJ: Ethnobotany and sustainable uses of plant resource in the HKH mountain region. Planning workshop on ethnobotany and its application to conservation and community development, in the Hindukush Himalayan (HKH) region. Nepal; 1995:75-80.

3. Cavender A: Folk medicinal uses of plant foods in southern Appalchia, United States. J Ethnopharmacol 2006, 108:74-84.

4. Pieroni A, Houlihan L, Ansari N, Hussain B, Aslam S: Medicinal perceptions of vegetables traditionally consumed by south- Asian migrants living in Bradford, Northern England. J Ethnopharmacol 2007, 113:100-110.
5. Ladio AH, Lozada M: Patterns of use and knowledge of wild edible plants in distinct ecological environments: a case study of a Mapuche community from northwestern Patagonia. Biodivers Conserv 2004, 13:1153-1173.

6. Pimentel D, Nair MM, Buck L, Pimentel M, Kami J: The value of forests to world food security. Human Ecol 1997, 25:91-120.

7. Heywood V, Skoula M: The MEDUSA Network: Conservation and sustainable use of wild plants of the Mediterranean region. In Perspectives on new crops and new uses. Edited by Janick J. Alexandria, VA: ASHS Press; 1999:148-151.

8. Bhattarai NK: Home herbal remedies of the urban population of Kathmandu valley, Nepal. J Nepal Pharmaceut Assoc 1998, 15(1-2):13-27.

9. Dutta A, Pant $\mathrm{K}$ : The nutritional status of indigenous people in the Garwal Himalayas, India. Mount Res Develop 2003, 23(3):278-283.

10. Pattanayak S, Sills EO, Mehta AD, Kramer RA: Local use of parks: uncovering use of household production from forests of Siburet, Indonesia. Censer Society 2003, 1(2):209-222.

11. Pardo-de-Santayana M, Tardo J, Blanco E, Carvalho AM, Lastra JJ, San E, Miguel Morales R: Traditional knowledge of wild edible plants used in the northwest of the Iberian Peninsula (Spain and Portugal): a comparative study. J Ethnobiol Ethnomed 2007, 3:27.

12. Temple NJ: Antioxidants and disease: more questions than answers. Nutr Res 2000, 20:449-459.

13. Bazzano LA, He J, Ogden LG: Legume consumption and risk of coronary heart disease in US men and women: NHANES I epidemiologic follow-up study. Arch Inter Med 2001, 161:2573-2578.

14. Espin JC, Garcia-Conesa MT, Tomas-Barberan FA: Nutraceuticals: Facts and fiction: A Review. Toma's-Barbera'n. Phytochem 2007, 68:2986-3008.

15. Liu RH: Health benefits of fruits and vegetables are from additive and synergistic combination of phytochemicals. Americ J Clinic Nut 2003, 78:517S-520S.

16. Willett WC: Diet, nutrition, and avoidable cancer. Environ Health Perspect 1995, 103(8):165-170.

17. Ercisli S: Chemical composition of fruits in some Rose (Rosa spp.) species. Food Chem 2007, 104:1379-1384.

18. Misra S, Maikhuri RK, Kala CP, Rao KS, Saxena KG: Wild leafy vegetables: a study of their subsistence dietetic support to the inhabitants of Nanda Devi biosphere reserve, India. J Ethnobiol. Ethnomed 2008, 4:15.

19. Hadjichambis ACH, Hadjichambi DP, Della A, Giusti ME, Pasquale DC, Lenzarini C, Censorii E, Tejero MRG, Rojas CPS, Gutierrez JRR, Skoula M, Johnson CH, Sarpakia A, Hmomouchiv M, Jorhi S, Demerdash ME, Zayat M, Pioroni A: Wild and semi-domesticated food plant consumption in seven circum-Mediterranean areas. Inter J Food Sci Nut 2008, 59:383-414.

20. Pieroni A, Nebel S, Santoro RF, Heinrich M: Food for two seasons: Culinary uses of non-cultivated local vegetables and mushrooms in a south Italian village. Int J Food Sci Nut 2005, 56:245-272.

21. Hussain F, llahi I: Ecology and Vegetation of Lesser Himalayas Pakistan. Peshawar, Pakistan: Jadoon Printing Press; 1991:1-185.

22. Pakistan Bureau of Statistics: Statistical Year Book. Islamabad, Pakistan: Government of Pakistan; 2008.

23. Khan SU, Hasan MU, Khan FK, Bari A: Climate classification of Pakistan. Balwois Conference: Republic of Macedonia; 2010:1-47.

24. Cotton CM: Ethnobotany Principles and Applications. Chichester, New York: John Wiley and Sons; 1996.

25. Mengistu F, Herbert H: Wild Edible Fruit Species Cultural Domain, Informant Species Competence and Preference in Three Districts of Amhara Region, Ethiopia. Ethnobot Res Applic 2008, 6:487-502.

26. Ali SI, Qaiser M: Flora of Pakistan. Karachi-Pakistan: 1995-2005, Botany Department, University of Karachi.

27. Galeano G: Forest use at the Pacific coast of Choco, Colombia: A quantitative approach. Eco Bot 2000, 54:358-376.

28. Balemie K, Kebebew F: Ethnobotanical study of wild edible plants in Derashe and Kucha Districts, South Ethiopia. J Ethnobiol Ethnomed 2006, 2:53.

29. Levetin E, Mcmahon K: Plant and society. 2nd edition. Dubuque, lowa: WCB/ McGraw-Hill; 1999

30. Abbasi AM, Khan MA, Ahmad M, Zafar M: Medicinal plant biodiversity of Lesser Himalayas-Pakistan. New York: Springer; 2012:1-212.

31. Shinwari ZK, Rehman M, Watanabe T, Yoshikawa Y: Medicinal and Aromatic Plants of Pakistan (A Pictorial Guide). Kohat, Pakistan: Kohat University of Science and Technology; 2006:492. 
32. Shinwari ZK, Khan J, Naz S, Hussain A: Screening of medicinal plants of Pakistan for their antibacterial activity. Afric J Biotech 2009, 8(24):7082-7086.

33. Abbasi AM, Khan MA, Ahmad M, Zafar M, Jahan S, Sultana S Ethnopharmacological application of medicinal plants to cure skin diseases and in folk cosmetics among the tribal communities of NorthWest Frontier Province, Pakistan. J Ethnopharmacol 2010, 128:322-335.

34. Abbasi AM, Khan MA, Ahmad M, Zafar M, Khan H, Muhammad N, Sultana S: Medicinal plants used for the treatment of jaundice and hepatitis based on socio-economic documentation. Afric J Biotech 2009, 8:1643-1650.

35. Abbasi AM, Khan MA, Zafar M: Ethno-medicinal assessment of some selected wild edible fruits and vegetables of Lesser-Himalayas, Pakistan. Pak J Bot 2013, 45(SI):215-222.

36. Afzal S, Afzal N, Awan AR, Khan TS, Gilani A, Rizwana K, Sumbal T: Ethnobotanical studies from Northern Pakistan. J Ayub Med Coll Abbott 2009, 21:212-219.

37. Ahmad SS, Husain SZ: Ethnomedicinal survey of plants from Salt Range (Kalar Kahar), Pakistan. Pak J Bot 2008, 40:1005-1011.

38. Ali H, Qaiser M: The ethnobotany of Chitral valley, Pakistan with particular reference to medicinal plants. Pak J Bot 2009, 41:2009-2041.

39. Barkatullah, Ibrar M, Hussain F: Ethnobotanical studies of plants of Har kotli Hills, Batkhela District, Malakand, Pakistan. Front Bull 2009. 4:539-548.

40. Hazrat A, Nisar M, Shah J, Ahmad S: Ethnobotanical study of some elite plants belonging to Dir, Kohistan valley, Khyber Pukhtunkhwa, Pakistan. Pak J Bot 2011, 43(2):787-795.

41. Hussain K, Shahzad A, Hussnain SZ: An Ethnobotanical survey of important wild medicinal plants of Hattar District Haripur, Pakistan. Ethnobot Leaflets 2008, 12:29-35.

42. Ignacimuthu S, Ayyanar M, Sankara SK: Ethnobotanical investigations among tribes in Madurai District of Tamil Nadu (India). J Ethnobiol Ethnomed 2006, 2:25.

43. Jan G, Khan MA, Gul F: Ethnomedicinal plants used against diarrhea and dysentery in Dir Kohistan valley (NWFP), Pakistan. Ethnobot Leaflets 2008 12:620-637.

44. Jan G, Khan MA, Gul F: Medicinal Value of the Asteraceae of Dir Kohistan Valley, NWFP, Pakistan. Ethnobot Leaflets 2009, 13:1205-1215.

45. Kamal M, Sultan MW, Muhammad H, Subhan M, Saad UK, Asim M, Shaheen T: Ethnobotanically important plants of District Bannu, Pakistan. Pak J Plant Sci 2009, 15:87-93.

46. Noor MJ, Kalsoom U: Ethnobotanical studies of selected plant species of Ratwal village, District Attock, Pakistan. Pak J Bot 2011, 43:781-786.

47. Parveen B, Upadhyay, Shikha R, Ashwani K: Traditional uses of medicinal plants among the rural communities of Churu district in the Thar Desert, India. J Ethnopharmacol 2007, 113:387-399.

48. Pieroni A: Medicinal plants and food medicines in the folk traditions of the upper Lucca Province. Italy J Ethnopharmacoly 2000, 70:235-273.

49. Qureshi R, Bhatti RG, Memon RA: Ethnomedicinal uses of herbs from northern part of Nara Desert. Pak J Bot 2010, 42(2):839-851.

50. Saikia AP, Venkat KR, Pragya S, Pranab G, Utpal B: Ethnobotany of medicinal plants used by Assamese people for various skin ailments and cosmetics. J Ethnopharmacol 2006, 106:149-157.

51. Sher H, Hussain F: Ethnobotanical evaluation of some plant resource in northern parts of Pakistan. Afri J Biotech 2009, 8:4066-4076.

52. Sher Z, Zaheer UDK, Farrukh H: Ethnobotanical studies of some plants of Chagharzai valley, District Buner, Pakistan. Pak J Bot 2011, 43:1445-1452

53. Tene V, Omar M, Paola VF, Giovanni V, Chabaco A, Tom'as Z: An ethnobotanical survey of medicinal plants used in Loja and ZamoraChinchipe, Ecuador. J Ethnopharmacol 2007, 111:63-81.

54. Marwat SK, Rehman FU, Usman K, Khakwani AZ, Ghulam S, Anwar N, Sadiq M, Khan SJ: Medico-ethnobotanical studies of edible wild fruit plants species from the flora of north western Pakistan (D. I. Khan district). J Med Plants Res 2011, 5:3679-3686.

55. Khan MA, Khan MA, Hussain M, Mujtaba G: An ethnobotanical inventory of Himalayan region Poonch valley Azad Kashmir (Pakistan). Ethnobot Res Applic 2010, 8:107-123.

56. Shale TL, Stirk WA, Van SJ: Screening of medicinal plants used in Lesotho for antibacterial and anti-inflammatory activity. J Ethnopharmacol 1999, 67:347-354.

57. Zheng $X \mathrm{~L}$, Xing FU: Ethnobotanical study on medicinal plants around Mt. Yinggeling, Hainan Island, China. J Ethnopharmacol 2009, 124:197-210.
58. Kumar S, Irshad AH: Wild edibles of Kishtwar high altitude national park in northwest Himalaya, Jammu and Kashmir (India). Ethnobot Leaflets 2009, 13:195-202.

59. Tiwari JK, Ballabha R, Tiwari P: Some promising wild edible plants of Srinagar and its adjacent area in Alaknanda valley of Garhwal Himalaya, India. J Americ Sci 2010, 6:167-177.

60. Savithramma N, Sulochana C, Rao KN: Ethnobotanical survey of plants used to treat asthma in Andhra Pradesh, India. J Ethnopharmacol 2007, 113:54-61.

61. Saqib Z, Sultan A: Ethnobotany of Palas valley, Pakistan. Ethnobot Leaflets 2005, 5:1350-1357.

62. Albuquerque UP, Andrade LHC, Silva ACO: Use of plant resources in a seasonal dry forest (Northeastern Brazil). Acta Bot Brasil 2005, 19:27-38

63. Tardio J, Santayana PD: Cultural Importance Indices: a Comparative Analysis based on the useful wild plants of southern Cantabria (Northern Spain). Eco Bot 2008, 62:24-39.

64. Bonet MA, Parada M, Selga A, Vallès J: Studies on pharmaceutical ethnobotany in the regions of L'Alt Empordà and Les Guilleries (Catalonia, Iberian Peninsula). J Ethnopharmacol 1999, 68:145-168.

65. Bonet MA, Vallès J: Use of non-crop food vascular plants in Montseny biosphere reserve (Catalonia, Iberian Peninsula). Inter J Food Sci Nut 2002, 53:225-248.

66. Johns T, Kokwaro JO, Kimanani EK: Herbal remedies of the Luo Siaya District, Kenya: Establishing qualitative criteria for consensus. Eco Bot 1990, 44(3):369-381.

67. Stepp JR, Moerman DE: The importance of weeds in ethnopharmacology. J Ethnopharmacol 2001, 75:25-31

\section{doi:10.1186/1746-4269-9-66}

Cite this article as: Abbasi et al:: Ethnobotanical appraisal and cultural values of medicinally important wild edible vegetables of Lesser Himalayas-Pakistan. Journal of Ethnobiology and Ethnomedicine 2013 9:66.

\section{Submit your next manuscript to BioMed Central and take full advantage of:}

- Convenient online submission

- Thorough peer review

- No space constraints or color figure charges

- Immediate publication on acceptance

- Inclusion in PubMed, CAS, Scopus and Google Scholar

- Research which is freely available for redistribution 